\title{
PERBEDAAN KEMAMPUAN PEMECAHAN MASALAH MATEMATIS SISWA MENGGUNAKAN MODEL STAD DAN PEMBELAJARAN LANGSUNG
}

\author{
Anggita Ulan Nasution, Asmin \\ ${ }^{1}$ Fakultas Matematika dan Ilmu Pengetahuan Alam, Universitas Negeri Medan \\ anggitaulannasution@ymail.com
}

\begin{abstract}
ABSTRAK
Penelitian ini bertujuan untuk mengetahui apakah kemampuan pemecahan masalah matematis siswa yang diajarkan dengan model pembelajaran kooperatif tipe STAD lebih tinggi daripada siswa yang di ajarkan dengan model pembelajaran langsung pada siswa kelas VIII SMP Muhammadiyah 3 Medan. Populasi dalam penelitian ini adalah seluruh siswa kelas VIII SMP Muhammadiyah 3 Medan dan sampel dalam penelitian ini adalah siswa kelas VIII-A dan kelas VIII-B sebanyak 72 siswa. Kelas VIII-A diberi STAD dan kelas VIII-B diberi pembelajaran langsung. Jenis penelitian ini adalah eksperimen semu. Dari analisis data pada kelas eksperimen diperoleh nilai rata-rata pre test 58,18 dan simpangan baku pre test 7,62 sedangkan nilai rata-rata post test 86,70. Pada kelas kontrol diperoleh nilai rata-rata pre test 58,14 dan simpangan baku pre test 8,70 sedangkan nilai rata-rata post test 78,28 . Dari analisis data postest dengan menggunakan uji-t pada taraf $\alpha=0,05$ diperoleh $t_{\text {hitung }}=2,12$ dan $t_{\text {tabel }}=1,668$ yang ternyata $t_{\text {hitung }}>t_{\text {tabel }}$ maka $H_{0}$ ditolak dan $H_{a}$ diterima. Maka dapat disimpulkan bahwa kemampuan pemecahan masalah matematis siswa yang diajar dengan menerapkan model pembelajaran STAD lebih tinggi daripada siswa yang diajar dengan pembelajaran langsung pada materi kubus dan balok.
\end{abstract}

\section{Kata kunci: Kemampuan Pemecahan Masalah Matematika, STAD, Pembelajara} Langsung

\begin{abstract}
The aim of this research were to know whether the problem solving skills of mathematics students who was taught by using cooperative learning model STAD type is higher than students who was taught by using direct instruction in class VIII SMP Muhammadiyah 3 Medan. The population in this research was all of the students in class VIII SMP Muhammadiyah 3 Medan and the sampel are the students in class VIII-A and VIII-B which total 72 students. Class VIII-A was taught by using STAD and class VIII-B was taught by using direct intrustion. This is quasi experiment. The result of this research the mean of pretest of the data in experiment class was 58,18 and standard devision of pretest 7,62 although the mean of posttest 86,70. The result of this research the mean of pretetst of the data in control class was 58,14 and standard devision of pretetst 8,70 although the mean of the data posttest 78,28. From the analysis data of posttest with using $t$-test with $\alpha=0,05$, the result $t_{\text {hitung }}=2,12$ and $t_{\text {tabel }}=1,668$ and evidently $t_{\text {hitung }}>$ $t_{\text {tabel }}$ so $H_{0}$ was rejected dan $H_{a}$ was accepted. So the conclusion is problem solving skills of mathematics students who was taught by using cooperative learning model STAD type is higher than students who was taught by using direct instruction.
\end{abstract}

Keywords : Mathematics Problem Solving Ability, STAD, Direct Instruction

Anggita Ulan Nasution, Asmin Perbedaan Kemampuan Pemecahan Masalah Matematis Siswa Menggunakan Model STAD dan Pembelajaran Langsung. Jurnal Inspiratif, Vol. 3, No. 2 Agustus 2017. 


\section{Pendahuluan}

Pendidikan merupakan wadah kegiatan yang dapat dipandang sebagai pencetak sumber daya manusia yang bermutu tinggi. Pendidikan bukanlah suatu hal yang statis atau tetap, melainkan suatu hal yang dinamis sehingga menuntut adanya suatu perbaikan secara terus-menerus. Perubahan dapat dilakukan dalam hal metode mengajar.

Dalam pembelajaran di sekolah, matematika merupakan salah satu mata pelajaran yang masih dianggap sulit dipahami oleh siswa yang tidak memiliki keterampilan yang cukup. Keberhasilan kegiatan belajar mengajar di sekolah dapat dilihat dari berbagai aspek, tidak terkecuali peran guru yang harus mengkondisikan proses pembelajaran. Pendidikan dan pembelajaran merupakan suatu proses yang diarahkan untuk mengembangkan potensi manusia agar memiliki kemampuan dalam perilaku kognitif, afektif, dan psikomotor (Tristiyanti,2016:4).

Matematika merupakan mata pelajaran wajib pada setiap jenjang pendidikan di Indonesia, mulai dari sekolah dasar hingga perguruan tinggi. Menurut Wardhani (dalam Delyana,2015:26) "Salah satu pembelajaran matematika di sekolah adalah memecahkan masalah yang meliputi kemampuan memahami masalah, merancang model matematika, menyelesaikan model, dan menafsirkan solusi yang diperoleh".

$$
\text { Menurut Gagne (dalam }
$$

Madawistama, 2014:259), "bahwa keterampilan intelektual paling tinggi dapat dikembangkan melalui pemecahan masalah". Untuk meningkatkan kemampuan peserta didik dalam memecahkan masalah matematik, salah satu cara yang dapat dilakukan adalah dengan jalan membiasakan peserta didik mengajukan masalah, soal, atau pertanyaan matematik sesuai dengan situasi yang diberikan oleh guru. Hal ini sejalan dengan pendapat Hartono (2013:3) yang mengatakan bahwa: Pemecahan masalah merupakan bagian dari kurikulum matematika yang sangat penting. Hal ini dikarenakan siswa akan memperoleh pengalaman dalam menggunakan pengetahuan serta keterampilan yang dimiliki untuk menyelesaikan soal yang tidak rutin. Sependapat dengan pernyataan tersebut, Lencher mendefenisikan pemecahan masalah matematika sebagai "proses menerapkan pengetahuan matematika yang telah diperoleh sebelumnya ke dalam situasi baru yang belum dikenal". Sebagai implikasinya, aktivitas pemecahan masalah dapat menunjang perkembangan kemampuan matematika yang lain seperti komunikasi dan penalaran matematika. Rendahnya kemampuan pemecahan masalah matematika siswa juga diungkapkan oleh Hoiriyah (2015:65-66) dalam penelitiannya, yaitu "bahwa dari 40 orang siswa terdapat $70 \%$ siswa yang belum mampu menuliskan apa yang diketahui dan ditanyakan, $75 \%$ siswa belum mampu merencanakan penyelesaian masalah, $80 \%$ siswa belum mampu melakukan perhitungan dengan benar, dan $90 \%$ siswa belum bisa memeriksa kembali prosedur dan hasil penyelesaian". Dalam hal ini peneliti memilih model pembelajaran Student Team Achievement Divison (STAD). Pembelajaran kooperatif tipe Student Teams Achievement Division (STAD) merupakan salah satu tipe dari model pembelajaran kooperatif dengan menggunakan kelompok-kelompok kecil dengan jumlah anggota tiap kelompok 45 orang yang saling membantu satu sama lain dan merupakan campuran tingkat kemampuan, jenis kelamin dan suku. Pada hakikatnya model ini menggali dan mengembangkan keterlibatan siswa secara aktif dalam proses belajar mengajar untuk meningkatkan pemahaman materi melalui kerjasama kelompok.

Anggita Ulan Nasution, Asmin Perbedaan Kemampuan Pemecahan Masalah Matematis Siswa Menggunakan Model STAD dan Pembelajaran Langsung. Jurnal Inspiratif, Vol. 3, No. 2 Agustus 2017. 
Menurut Gusniar (2014:203) kelebihan dari model pembelajaran kooperatif tipe STAD adalah:

$$
\begin{aligned}
& \text { (1) } \begin{array}{l}
\text { Dapat memberikan kesempatan } \\
\text { kepada } \\
\text { menggunakan }
\end{array} \\
& \text { bertanya dan membahas suatu } \\
& \text { masalah, } \\
& \text { dapat memberikan kesempatan } \\
& \text { kepada siswa untuk lebih } \\
& \text { intensif } \\
& \text { penyelidikan mengenai suatu } \\
& \text { masalah, }
\end{aligned}
$$

\section{Tinjauan Pustaka}

\section{A. Kemampuan Pemecahan Masalah}

Masalah yang dihadapi seseorang belum tentu menjadi masalah bagi orang lain. Hal ini disebabkan kemungkinan bahwa orang lain tersebut pernah mendapati dan memecahkan masalah seperti seseorang tersebut. Suatu masalah yang datang mengakibatkan orang tersebut agar berusaha untuk menyelesaikan masalah yang sedang dihadapinya. Sehingga dia harus menggunakan berbagai cara seperti berpikir, mencoba, dan bertanya untuk menyelesaikan masalahnya tersebut.

Menurut Hartono (2013:4), "Kemampuan pemecahan masalah matematika merupakan cara berpikir yang dapat digunakan ketika hendak menyelesaikan suatu masalah yang dapat diselesaikan dengan cabang ilmu matematika. Penyelesaian atau pemecahan suatu masalah dapat ditempuh seseorang dengan berbagai macam metode maupun strategi."

Akan tetapi, yang menjadi persoalan adalah bagaimana menentukan strategi yang terbaik dan terefisien. Hal ini terkait dengan menjadikan masalah yang kita hadapi terlihat lebih sederhana
(3) dapat mengembangkan bakat kepemimpinan dan mengajarkan keterampilan berdiskusi, dapat memungkinkan guru untuk lebih memperhatikan siswa sebagai individu dan kebutuhan belajarnya,

(5) para siswa lebih aktif bergabung dalam pelajaran mereka dan mereka lebih aktif dalam diskusi, (6) dapat memberikan kesempatan kepada siswa untuk mengembangkan rasa menghargai, menghormati pribadi temannya, dan menghargai pendapat orang lain.

sehingga mudah untuk dipecahkan. Sama halnya dengan menghadapi masalah matematika, kita harus jeli dalam menentukan strategi ataupun metode yang paling tepat.

Pemecahan masalah merupakan bagian dari kurikulum matematika yang sangat penting. Hal ini dikarenakan siswa akan memperoleh pengalaman dalam menggunakan pengetahuan serta keterampilan yang dimiliki untuk menyelesaikan soal yang tidak rutin. Sependapat dengan pernyataan tersebut, Lencher (dalam Hartono, 2013:3) mendefenisikan "Pemecahan masalah matematika sebagai proses menerapkan pengetahuan matematika yang telah diperoleh sebelumnya ke dalam situasi baru yang belum dikenal". Sebagai implikasinya, aktivitas pemecahan masalah dapat menunjang perkembangan kemampuan matematika yang lain seperti komunikasi dan penalaran matematika.

Pentingnya kemampuan pemecahan masalah oleh siswa dalam matematika ditegaskan dalam Syaiful (2012:37). Kemampuan pemecahan

Anggita Ulan Nasution, Asmin Perbedaan Kemampuan Pemecahan Masalah Matematis Siswa Menggunakan Model STAD dan Pembelajaran Langsung. Jurnal Inspiratif, Vol. 3, No. 2 Agustus 2017. 
masalah matematika siswa harus dikembangkan karena:

1. Kemampuan pemecahan masalah merupakan tujuan umum pengajaran matematika, bahkan sebagai jantungnya matematika;

2. Penyelesaian masalah yang meliputi metode, prosedur dan strategi merupakan proses inti dan utama dalam kurikulum matematika;

3. Pemecahan masalah merupakan kemampuan dasar dalam belajar matematika

\section{B. Model Pembelajaran Kooperatif Tipe STAD}

Student Team Achievement Division (STAD) merupakan salah satu model pembelajaran kooperatif yang di dalamnya beberapa kelompok kecil siswa dengan level kemampuan akademik yang berbeda-beda saling bekerja sama untuk menyelesaikan tujuan pembelajaran. Tidak hanya secara akademik, siswa juga dikelompokkan secara beragam berdasarkan gender, ras, dan etnis. Strategi ini pertama kali dikembangkan oleh Robert Slavin dan rekan-rekannya di Johns Hopkins University (Huda,2014:201).

Student Team Achievement Division (STAD) dikembangkan oleh Robert Slavin dan koleganya di Universitas John Hopkin dan merupakan pendekatan pembelajaran kooperatif yang paling sederhana. Guru yang menggunakan STAD, juga mengacu kepada belajar kelompok siswa, menyajikan informasi akademik baru kepada siswa setiap minggu menggunakan presentasi verbal atau teks. Siswa dalam suatu kelas tertentu dipecah menjadi kelompok dengan anggota 4-5 orang, setiap kelompok haruslah heterogen, terdiri dari laki-laki dan perempuan berasal dari berbagai suku, memiliki kemampuan tinggi,sedang, dan rendah.

Slavin (dalam Trianto,2011:68) menyatakan bahwa:
Pada STAD siswa yang ditempatkan dalam belajar beranggotakan 4-5 orang yang merupakan campuran menurut tingkat prestasi, jenis kelamin dan suku. Guru menyajikan pelajaran, dan kemudian siswa bekerja dalam tim mereka memastikan bahwa seluruh anggota tim telah menguasai pelajaran tersebut. Kemudian, seluruh siswa diberikan tes tentang materi tersebut, pada saat tes ini mereka tidak diperbolehkan saling membantu.

\section{Model Pembelajaran Langsung}

Pengajaran langsung adalah suatu model pengajaran yang bersifat teacher center. Adapun menurut Arends: Model pengajaran langsung adalah salah satu pendekatan mengajar yang dirancang khusus untuk menunjang proses belajar siswa yang berkaitan dengan pengetahuan deklaratif dan pengetahuan prosedural yang terstruktur dengan baik yang dapat diajarkan dengan pola kegiatan yang bertahap, selangkah demi selangkah. Selain itu, model pembelajran ini juga ditujukan untuk membantu siswa mempelajari keterampilan dasar dan memperoleh informasi yang dapat diajarkan selangkah demi selangkah.

Ciri-ciri model pengajaran langsung sebagai berikut:

1. Adanya tujuan pembelajaran dan pengaruh model pada siswa termasuk prosedur penilaian belajar.

2. Sintaks atau pola keseluruhan dan alur kegiatan pembelajaran

3. Sistem pengelolaan dan lingkungan belajar model yang diperlukan agar kegiatan pembelajaran tertentu dapat berlangsung dengan berhasil (Trianto, 2014: 93-94).

Anggita Ulan Nasution, Asmin Perbedaan Kemampuan Pemecahan Masalah Matematis Siswa Menggunakan Model STAD dan Pembelajaran Langsung. Jurnal Inspiratif, Vol. 3, No. 2 Agustus 2017. 
Menurut Majid langkah-langkah pembelajaran model pembelajaran langsung adalah:

1. Menyampaikan tujuan dan menyiapkan siswa

2. Mendemostrasikan pengetahuan atau kemampuan

3. Membimbing pelatihan

4. Mengecek pemahaman dan memberi umpan balik

5. Memberikan kesempatan untuk pelatihan lanjutan dan penerapan (Noor,2014:252).

\section{Metode Penelitian}

Penelitian ini dilaksanakan di SMP Muhammadiyah 3 Medan yang berlokasi di Jalan Abdul Hakim No. 2 Medan pada semester genap tahun ajaran 2016/2017.

Populasi dalam penelitian ini adalah seluruh siswa kelas VIII SMP Muhammadiyah 3 Medan yang terdiri dari 7 kelas, sedangkan yang menjadi sampel dalam penelitian ini adalah kelas VIII-A yang terdiri dari 38 siswa sebagai kelas eksperimen dan kelas VIII-B yang terdiri dari 36 siswa sebagai kelas kontrol.

Variabel bebas dalam penelitian ini adalah pembelajaran kooperatif tipe STAD dan pembelajaran langsung, sedangkan variabel terikatnya adalah kemampuan pemecahan masalah matematika siswa pada materi kubus dan balok

Jenis penelitian yang digunakan dalam penelitian ini adalah kuasi eksperimen yang bertujuan untuk mengetahui apakah kemampuan pemecahan masalah matematika siswa yang belajar dengan menggunakan model pembelajaran kooperatif tipe STAD lebih tinggi dibandingkan dengan siswa yang belajar dengan menggunakan model pembelajaran langsung.

Desain penelitian yang digunakan dalam penelitian ini adalah Posttest Only Control Group Design. Instrumen yang digunakan untuk memperoleh data dalam penelitian ini adalah posttest tes kemampuan pemecahan masalah matematika siswa yang terdiri dari empat butir soal berbentuk uraian. Analisis data dalam penelitian ini terdiri dari pengujian normalitas, pengujian homogenitas, dan pengujian hipotesis.

\section{Hasil Peelitian}

Setelah diketahui kemampuan awal, dilakukan pembelajaran dengan dua model pembelajaran yang berbeda pada kedua kelas, yaitu kelas eksperimen $\left(\mathrm{X}_{1}\right) \quad$ diterapkan pembelajaran Student Teams Achievement Division (STAD), sedangkan kelas kontrol $\left(\mathrm{X}_{2}\right)$ diterapkan pembelajaran Direct Instruction (Pembelajaran Langsung). Pada akhir pertemuan, siswa kembali diberikan posttest.Soal yang diberikan berbentuk uraian yang berjumlah 5 butir. Sebelum soal tersebut diberikan, dilakukan validasi soal kepada 3 orang ahli dan semua soal valid sehingga soal layak untuk diberikan kepada siswa.

Dari hasil posttest diperoleh bahwa rata-rata nilai posttest kelas eksperimen Isebesar 87,62 dan kelas kontrol sebesar 78,28 .

Berdasarkan hasil jawaban siswa kelas eksperimen yang diberikan pada tes akhir (posttest) dideskripsikan tingkat kemampuan pemecahan masalah matematis siswa. Dari hasil posttest yang diberikan dengan soal yang dibuat mencakup indikator pemecahan masalah matematis siswa yaitu memahami masalah, merancang model matematika, menjalankan rancangan model, dan menafsirkan hasil yang diperoleh, diperoleh bahwa kemampuan rata-rata siswa pada aspek memahami masalah dikelas eksperimen sebesar 99,67\% dan kelas kontrol sebesar 86,29\%, kemampuan rata-rata siswa pada aspek merancang model matematika kelas eksperimen sebesar 97,56\% dan kelas kontrol sebesar $88,86 \%$, kemampuan rata-rata siswa pada aspek menjalankan rancangan model kelas eksperimen sebesar $92,07 \%$ dan kelas kontrol

Anggita Ulan Nasution, Asmin Perbedaan Kemampuan Pemecahan Masalah Matematis Siswa Menggunakan Model STAD dan Pembelajaran Langsung. Jurnal Inspiratif, Vol. 3, No. 2 Agustus 2017. 
sebesar $79,42 \%$, kemampuan rata-rata siswa pada aspek menafsirkan hasil yang diperoleh kelas eksperimen sebesar $54,72 \%$ dan kelas kontrol sebesar $52,85 \%$. Berikut disajikan dalam bentuk diagram:

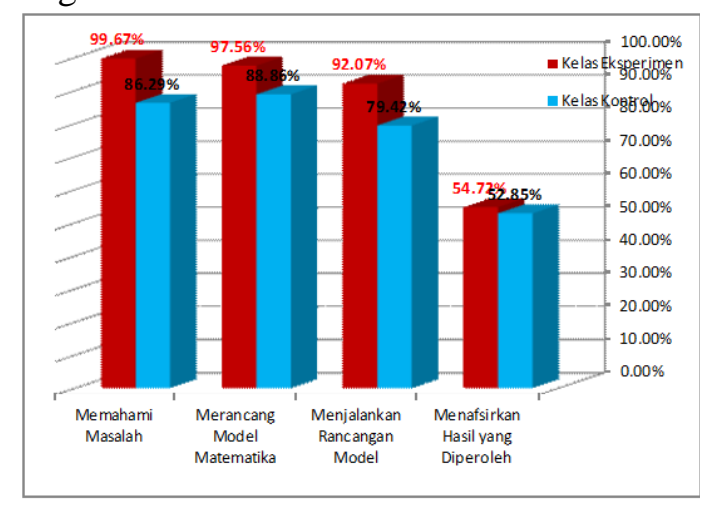

Gambar 1 Hasil jawaban Siswa

Setelah pembelajaran selesai dilakukan postes untuk mengetahui bagaimana kemampuan pemecahan masalah matematis siswa pada kedua kelas. Dari hasil postes diperoleh nilai rata-rata siswa kelas eksperimen yaitu 86,70 dan kelas kontrol yaitu 78,28. Kemudian dilakukan pengujian normalitas dan homogenitas dan diperoleh bahwa data kedua kelas kelas berdistribusi normal dan homogen. Artinya bahwa kedua kelas dapat mewakili seluruh populasi di kelas VIII SMP Muhammadiyah 3 Medan. Setelah diketahui bahwa kedua kelas berdistribusi normal dan homogen, maka dilakukan pengujian hipotesis untuk kemampuan pemecahan masalah matematis siswa dengan menggunakan uji-t. Setelah dilakukan pengujian data, ternyata diperoleh hasil pengujian kemampuan pemecahan masalah matematis pada taraf signifikansi $\alpha=$ $0,05, t_{\text {hitung }}>t_{\text {tabel }}$ yaitu $2,1241>$ 1,668, maka $\mathrm{H}_{\mathrm{o}}$ ditolak dan $\mathrm{H}_{\mathrm{a}}$ diterima. Dengan demikian dapat disimpulkan bahwa kemampuan pemecahan masalah matematis siswa yang diajar dengan model pembelajaran Student Team Achievement Division (STAD) lebih tinggi daripada siswa yang diajar dengan model pembelajaran langsung.

\section{Pembahasan}

Berdasarkan fakta yang ditemukan peneliti diperoleh bahwa siswa yang belajar dengan model pembelajaran kooperatif tipe STAD memiliki kemampuan pemecahan masalah yang lebih baik dibandingkan dengan siswa yang belajar dengan model pembelajaran langsung. Hal ini dikarenakan pada pembelajaran STAD siswa belajar dalam kelompok yang beranggotakan 5 orang yang heterogen dan pada pembelajaran ini ada pemberian penghargaan kepada kelompok yang dapat menyelesaikan masalah dengan baik, sehingga setiap siswa lebih bersemangat dalam memecahkan masalah. Sementara itu pada pembelajaran langsung siswa belajar secara individu dan pada pembelajaran ini memecahkan masalah terkadang mengalami keterbatasan, yang secara tidak langsung juga mengganggu kegiatan siswa dalam memecahkan masalah.

Pada setiap aspek kemampuan pemecahan masalah matematika, siswa kelas eksperimen atau yang belajar dengan menggunakan model pembelajaran kooperatif tipe STAD memperoleh nilai rata-rata yang lebih tinggi dibandingkan dengan siswa kelas kontrol atau yang belajar dengan menggunakan model pembelajaran langsung. Menurut Surya dan Rahayu (2014: 29) bahwa hal ini disebabkan karena dalam pembelajaran kooperatif tipe STAD terdapat belajar kelompok, sehingga siswa dapat bekerja sama dan saling membantu dalam mengatasi kesulitan-kesulitan yang dialaminya selama menyelesaikan permasalahan matematika. Dengan saling bekerja sama dan bertukar ide-ide matematika yang dimilikinya dapat melatih keterampilannya dalam memecahkan permasalahan matematika yang ada. Hal

Anggita Ulan Nasution, Asmin Perbedaan Kemampuan Pemecahan Masalah Matematis Siswa Menggunakan Model STAD dan Pembelajaran Langsung. Jurnal Inspiratif, Vol. 3, No. 2 Agustus 2017. 
tersebut bermanfaat bagi siswa dalam meningkatkan kemampuan pemecahan masalah matematikanya.

Selain itu jika dilihat dari tingkat kemampuan pemecahan masalah matematika siswa dari kedua kelas juga memiliki perbedaan. Siswa yang belajar dengan menggunakan model pembelajaran kooperatif tipe STAD memiliki tingkat kemampuan pemecahan masalah yang lebih baik dibandingkan dengan siswa yang belajar dengan menggunakan model pembelajaran langsung. Hal ini dapat dilihat dari lebih banyaknya siswa yang tingkat kemampuan pemecahan masalah matematikanya berkategori tinggi dan sangat tinggi pada kelas STAD siswa dibandingkan dengan kelas pembelajaran langsung yang banyaknya siswa dengan tingkat kemampuan pemecahan masalah matematika berkategori tinggi dan sangat tinggi lebih sedikit

\section{Kesimpulan}

Berdasarkan hasil penelitian dan pembahasan yang telah diuraikan pada bab sebelumnya maka disimpulkan bahwa : Kemampuan pemecahan masalah matematis siswa yang belajar dengan menggunakan model pembelajaran kooperatif tipe STAD lebih tinggi dari kemampuan pemecahan masalah matematis siswa yang belajar dengan menggunakan model pembelajaran langsung di SMP Muhammadiyah 3 Medan.

\section{Saran}

Berdasarkan hasil penelitian ini maka saran yang dapat peneliti berikan adalah:

1. Berdasarkan hasil penelitian bahwa pembelajaran matematika dengan model pembelajaran kooperatif tipe Student Teams Achievement Division (STAD) mampu meningkatkan kemampuan pemecahan masalah matematis siswa khususnya pada materi bangun ruang kubus dan balok, sehingga model pembelajaran ini dapat dijadikan sebagai salah satu variasi dalam pembelajaran matematika yang dapat diterapkan oleh guru.

2. Terdapat beberapa keterbatasan dalam penelitian ini, oleh karena itu sebaiknya dilakukan penelitian lanjut yang meneliti tentang pembelajaran matematika dengan model pembelajaran kooperatif tipe Student Teams Achievement Division (STAD) pada pokok bahasan lain, mengukur aspek lain serta pada jenjang sekolah yang berbeda.

3. Guru ataupun Peneliti Lanjutan yang hendak menggunakan model pembelajaran kooperatif tipe Student Teams Achievement Division (STAD) dalam pembelajaran di kelas diharapkan dapat mendesain pembelajaran dengan seefektif mungkin, sehingga pembelajaran dapat selesai tepat waktu.

\section{DAFTAR PUSTAKA}

Abdurrahman, M., (2012), Pendidikan Bagi Anak Kesulitan Belajar, Rineka Cipta, Jakarta.

Arikunto, S., (2013), Dasar-dasar Evaluasi Pendidikan Edisi 2, Bumi Aksara, Jakarta.

Dahar, R.W., (2006), Teori-Teori Belajar dan Pembelajaran, Erlangga, Bandung.

Danapriatna, N., Setiawan, R., (2005), Pengantar Statistika, Graha Ilmu, Yogyakarta.

Delyana, H., (2015), Peningkatan Kemampuan Pemecahan Masalah Matematika Siswa Kelas VII Melalui Penerapan Pendekatan Open Ended, Lemma, 2(1), 26-34.

Gusniar, (2014), Penerapan Model Pembelajaran Kooperatif Tipe Student Teams Achievment Division (STAD) Dalam

Anggita Ulan Nasution, Asmin Perbedaan Kemampuan Pemecahan Masalah Matematis Siswa Menggunakan Model STAD dan Pembelajaran Langsung. Jurnal Inspiratif, Vol. 3, No. 2 Agustus 2017. 
Meningkatkan Hasil Belajar Siswa Pada Mata Pelajaran IPS Kelas IV SDN No. 2 Ogoamas II, Jurnal Kreatif Tadulako Online, 2(1): 198-221.

Hoiriyah, D., (2015), Peningkatan Kemampuan Pemecahan Masalah Matematik dan SelfEfficacy Siswa Melalui Pembelajaran Berbasis Masalah di MAN 1 Padangsidimpuan, Jurnal Pendidikan Matematika, 3(1): 62-77.

Hartono,Y., (2013), Strategi Pemecahan Masalah, Graha Ilmu, Yogyakarta.

Rusman,

(2013), Model-Model

Pembelajaran

Mengembangkan

Profesionalisme

Guru,

Rajawali Press, Jakarta.

Sanjaya, W., (2006), Strategi

Pembelajaran Berorientasi

Standar Proses Pendidikan,

Kencana, Jakarta.

Shoimin, A., (2016), 68 Model Pembelajaran Inovatif dalam Kurikulum 2013, Ar- Ruzz Media, Yogyakarta.

Simorangkir, F. M. A., (2014),

Perbedaan Kemampuan

Pemecahan Masalah

Matematis Siswa yang

Diajar dengan Pembelajaran

Berbasis Masalah dan

Pembelajaran Langsung,

Jurnal Saintech, 6(4) :3034.

Siegel, S., (2011), Statistik Non Parametrik, Gramedia Pustaka Utama, Jakarta.

Soedjaji, R., (2000), Kiat Pendidikan Matematika di Indonesia, Direktorat Jendral Pendidikan Indonesia, Jakarta.

Sudjana, (2008), Metode Statistika, Tarsito, Bandung.

Suprapto, (2015), Pengaruh Model Pembelajaran Kooperatif Tipe
STAD Terhadap Peningkatan Kemampuan Representasi dan Pemecahan Masalah Matematis Siswa, Indoneisan Digital Journal of Mathematics and Education, 2(3) :153-164.

Surya, E.,dan Rahayu, R., (2014). Peningkatan Kemampuan Komunikasi dan Pemecahan Masalah Matematis Siswa ArRahman Percut Melalui Pembelajaran Kooperatif Tipe Student Teams Achievement Division (STAD), Jurnal Pendidikan Matematika Paradikma 7(1): 24-34.

Susanto, A., (2014), Teori dan Pembelajaran di Sekolah Dasar, Kencana. Jakarta.

Syah, M., (2012), Psikologi Belajar, Raja Grafindo Persada, Jakarta.

Trianto, (2014), Mendesain Model Pembelajaran Inovatif, Progresif, dan Konstektual, Kencana Prenada Media Group, Jakarta.

Tristiyanti, T. dkk., (2016), Kemampuan Pemecahan Masalah Matematis Siswa Melalui Model Pembelajaran Kooperatif Tipe Diskursus Multi Representasi dan Reciprocal Learning, Jurnal Silogisme: Kajian Ilmu Matematika dan Pembelajarannya, 1(2): 4-14.

Anggita Ulan Nasution, Asmin Perbedaan Kemampuan Pemecahan Masalah Matematis Siswa Menggunakan Model STAD dan Pembelajaran Langsung. Jurnal Inspiratif, Vol. 3, No. 2 Agustus 2017. 